\title{
Service manufacturing $=$ Process-as-a-Service + Manufacturing Operations-as-a-Service
}

\author{
Andrew Kusiak ${ }^{1}$ (D) \\ Published online: 2 January 2020 \\ ○) Springer Science+Business Media, LLC, part of Springer Nature 2020
}

Many functional areas of manufacturing have become services, e.g., IT-as-a-Service (ITaaS), Infrastructure-as-aService (IaaS). The conversion to services is to continue to include domains ranging from Platform-as-a-Service (PaaS) to Manufacturing-as-a-Service (MaaS). The pace of the Manufacturing-as-a-Service transformation will vary and is likely to prevail in industries embracing open manufacturing as opposed to the integrated production mode (Kusiak 2018). The open and integrated manufacturing emerge as two extreme configurations (see Fig. 1). Though most manufacturing will populate the space between the two extrema in the form of hybrid configurations, over time it will polarize towards one of two extrema.

The information and knowledge (e.g., about material, process, product) in the integration extreme will be highly proprietary as opposed to highly shared in the openness extreme. The two extrema will impact the nature of innovation. Integrated manufacturing is likely to support material, process, and component/assembly innovation, while the product and system level innovation is more amenable to open manufacturing (Kusiak 2016).

The term XaaS, where $\mathrm{X}$ is a function or a domain of activities, has been used rather loosely around manufacturing. In the absence of ontology, the Manufacturingas-a-Service was referred in Kusiak (2019) as Service Manufacturing.

Here the following definition of the Manufacturing-as-aService is used (see Fig. 2):

Andrew Kusiak

andrew-kusiak@uiowa.edu

https://research.engineering.uiowa.edu/kusiak/

1 Department of Industrial and Systems Engineering, 4627

Seamans Center, The University of Iowa, Iowa City,

IA 52242-1527, USA

\author{
Manufacturing-as-a-Service(MaaS) \\ $\equiv$ Service Manufacturing \\ $=$ Process-as-a-Service (PaaS) \\ + Manufacturing Operations-as-a-Service (MOaaS).
}

Note that the notion of Manufacturing-as-a-Service presented here is not related to the one used in other production contexts, e.g., manufacturing products with build-in sensors generating data that is monetized, servitization aiming at providing services and solutions complementing the usual product offerings (e.g., a manufacturer is paid for the time a product is used by a customer; a manufacturer provides a condition monitoring service for the product sold), or subcontracting component manufacturing where a manufacturer decides to externally produce certain components.

Service manufacturing is largely driven by resource sharing - the core concept of shared economy. While some corporations may find it difficult to embrace MaaS, the ones that will subscribe to it, may be the greatest beneficiaries of this new business phenomena. MaaS may unravel benefits stemming from greater utilization of capacity and resources to innovation and environmental friendliness.

The roadmap of service manufacturing faces some hurdles, both technology and people related. There is no doubt that the enthusiasm around smart manufacturing, including digitization, software platforms, and developments in soft and machine intelligence make measurable imprint on this roadmap (Kusiak 2017). It may take more systems of systems developments, vision, and trust to attain a perfect fusion of the technological solutions and the wealth of human enthusiasm, engagement, and ideas. 


\begin{tabular}{|c|c|c|}
\hline $\begin{array}{c}\text { Integrated } \\
\text { Manufacturing }\end{array}$ & $\begin{array}{c}\text { Hybrid } \\
\text { Manufacturing }\end{array}$ & $\begin{array}{c}\text { Open } \\
\text { Manufacturing }\end{array}$ \\
\hline $\mathbf{I M}$ & $\begin{array}{l}\text { Degree of openness } \\
\qquad(0-100 \%)\end{array}$ & OM \\
\hline $\begin{array}{l}\text { Integration } \\
\text { extreme }\end{array}$ & & $\begin{array}{r}\text { Openn } \\
\text { extre }\end{array}$ \\
\hline
\end{tabular}

Fig. 1 Extreme manufacturing configurations

Manufacturing-as-a-Service $\equiv$ Service Manufacturing

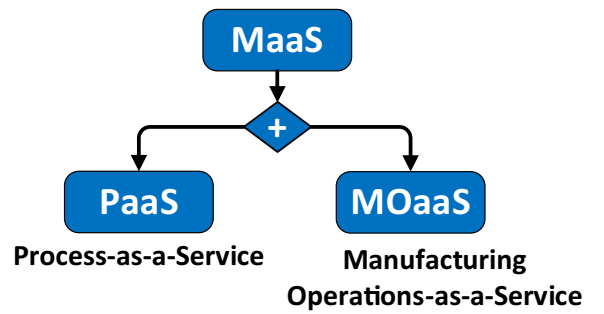

Fig. 2 Service manufacturing

\section{References}

Kusiak, A. (2016). Put innovation science at the heart of discovery. Nature, 530(7590), 255.

Kusiak, A. (2017). Smart manufacturing must embrace big data. Nature, 544(7648), 23-25.

Kusiak, A. (2018). Smart manufacturing. International Journal of Production Research, 56(1-2), 508-517.

Kusiak, A. (2019). Service manufacturing: Basic concepts and technologies. SME Journal of Manufacturing Systems, 52(Part A), 198-204.

Publisher's Note Springer Nature remains neutral with regard to jurisdictional claims in published maps and institutional affiliations. 